\title{
Penandaan Batas Area Perhutanan Sosial pada Desa Tombang Kecamatan Walenrang Kabupaten Luwu
}

\author{
Ahmad Ali Hakam Dani ${ }^{1}$ dan Apriyanto ${ }^{2}$ \\ ${ }^{1}$ Email: ahmad.ali.hd90@gmail.com \\ Universitas Andi Djemma \\ 22Email: apriyanto.mtk@unanda.ac.id \\ Universitas Andi Djemma
}

\begin{abstract}
Abstrak. Masyarakat Kelompok Tani Hutan Desa Tombang memiliki masalah terhadap lahan yang mereka kelola pada saat ini. Kegiatan Penadaan Batas Areal Kerja HPHD Tombang dapat membantu masyarakat untuk memberikan batas-batas fisik berupa plat batas pada areal kerja HPHD dan dalam rangka terwujudnya kepastian hukum mengenai status, batas, luas dan letak wilayah areal kelola. Metode yang digunakan pada kegiatan ini yaitu menggunakan pendekatan partisipatif dan kolaboratif yang melibatkan masyarakat, kelompok tani, polisi hutan, pemerintah desa, kementerian kehutanan dan perguruan tinggi dalam proses pemetaan penandaan tapal batas perhutanan sosial.
\end{abstract}

Kata Kunci: Perhutanan Sosial, Partisipatif dan Kolaboratif.

\section{PENDAHULUAN}

Penyelenggaran perhutanan sosial bertujuan untuk meningkatkan peran serta masyarakat dalam mengelola hutan yang dapat meningkatkan taraf kehidupan masyarakat. Perhutanan sosial sebagai kebijakan pengelolaan hutan dan menjadi tanggung jawab pemerintah selaku pengelola negara oleh Direktorat Jenderal Perhutanan Sosial dan Kemitraan Lingkungan Kementerian Lingkungan Hidup dan Kehutanan.

Rangkaian kegiatan yang dilaksanakan oleh Balai Perhutanan Sosial dan kemitraan Lingkungan dalam melaksanakan kegiatan penyiapan kawasan perhutanan sosial, pengembangan usaha pemanfaatan hutan dan kemitraan, serta pemetaan konflik di bidang perhutanan sosial dan kemitraan lingkungan. Adapun target kinerja pemerintah dalam program perhutanan sosial yaitu meningkatnya akses pengelolaan hutan oleh masyarakat, meningkatnya upaya penyelesaian konflik dan terurial di kawasan hutan dan meningkatnya perilaku peduli lingkungan dan kehutanan. Pemerintah telah menargetkan alokasi kawasan hutan seluas 12,7 juta ha yang dikelola masyarakat dengan skema Hutan Kemasyarakatan (HKm), Hutan Desa (HD), Hutan Tanaman Rakyat (HTR) dan Kemitraan Kehutanan.

Program kegiatan perhutanan sosial merupakan salah satu strategi resolusi konflik yang terjadi pada masyarat. Namun, pada beberapa asas dan tujuan terdapat unsur konflik disebabkan, diantaranya kebijakan program yang bersifat sentralistik (terpusat), tahapan pemberdayaan yang bersifat prosedural, serta penerapan batas/ arena aksi, aturan-aturan main dan penetapan stakeholders belum menjadi prioritas. Berkaitan dengan kebijakan pengembangan perhutanan sosial (social forestry), terdapat setidaknya dua hal penting sebagai pertimbangan dalam resolusi konflik, yakni dikotomi ruang lingkup program 
perhutanan sosial di dalam kawasan atau di luar kawasan hutan; dan fakta historis tentang pengelolaan hutan antara pulau Jawa dan luar pulau Jawa (sumanto, 2009).

Adapun tujuan dari pengembangan perhutanan sosial adalah melibatkan masyarakat yang mendiami sekitar dan di dalam kawasan hutan untuk turut serta memberdayakan sumber daya hutan yang ada, sehingga memberikan nilai tambah dalam meningkatkan kesejahteraan bagi masyarakat. Kegiatan ini difokuskan pada penataan batas luar dan fungsi kawasan hutan yang dilaksanakan oleh Balai Pemantapan Kawasan Hutan. Berkaitan dengan pemenuhan kewajiban pemberian tanda batas bagi pemegang HD, HKm dan HTR, yang dilakukan dengan menggunakan alat ukur kompas, meteran atau Global Positioning System (GPS) dengan tanda batas yang ditentukan.

\section{METODE}

Metode yang digunakan pada kegiatan tapal batas ini yaitu menggunakan pendekatan partisipatif dan kolaboratif dengan pelibatan masyarakat, kelompok tani, polisi hutan, pemerintah desa, kementerian kehutanan dan perguruan tinggi (Unanda). Kegiatan partisipatif ini dilakukan untuk menambah pemahaman warga tentang urgensi wilayah kehutanan yang memberikan manfaat bagi masyarakat. Pendekatan partisipatif ini pada prinsipnya harus melibatkan seluruh masyarakat dalam proses pelaksanaan kegiatan dan upaya untuk memecahkan masalah yang terjadi (Fisu dan Marzaman, 2018). Pentingnya metode partisipatif yang dilakukan secara berkelanjutan supaya dapat berbagi informasi dalam meningkatkan kemampuan dana perbaikan kehidupan masyarakat (Asnuddin, 2010).

\section{PEMBAHASAN \\ Pelaksanaan Kegiatan}

Adapun hal-hal yang dipersiapkan dalam kegiatan pelaksanaan kegiatan tapal batas hutan adalah persiapan alat dan bahan meliputi Peta Kerja dan Pedoman Tata Batas; Suratsurat yang diperlukan; Alat tulis menulis, camping unit, obat-obatan dan bahan/alat lainnya yang diperlukan di lapangan; Receiver GPS beserta pelengkapannya; Koordinasi dengan BPKH; dinas kehutanan lokasi penataan batas; dan masyarakat desa.

Tim pelaksana terdiri dari pelaksana inti sebanyak dua orang, satu orang saksi dari perguruan tinggi dan beberapa masyarakat pemegang hak pengelolaan perhutanan sosial. Pelaksana ini memiliki tugas menyusun pembuatan peta kerja penandaan batas; pengukuran dan pemetaan; membuat laporan, berita acara dan peta hasil penandaan batas areal kerja; dan peta penandaan batas areal kerja. Kegitan pekerjaan lapangan diawali dengan membukaan atau membuat rintis batas. Pembuatan rintis batas adalah pekerjaan menebas semak belukar ke arah dalam areal hutan kelola, sehingga dapat digunakan sebagai jalan inspeksi dan keperluan pengamanan batas hutan. 

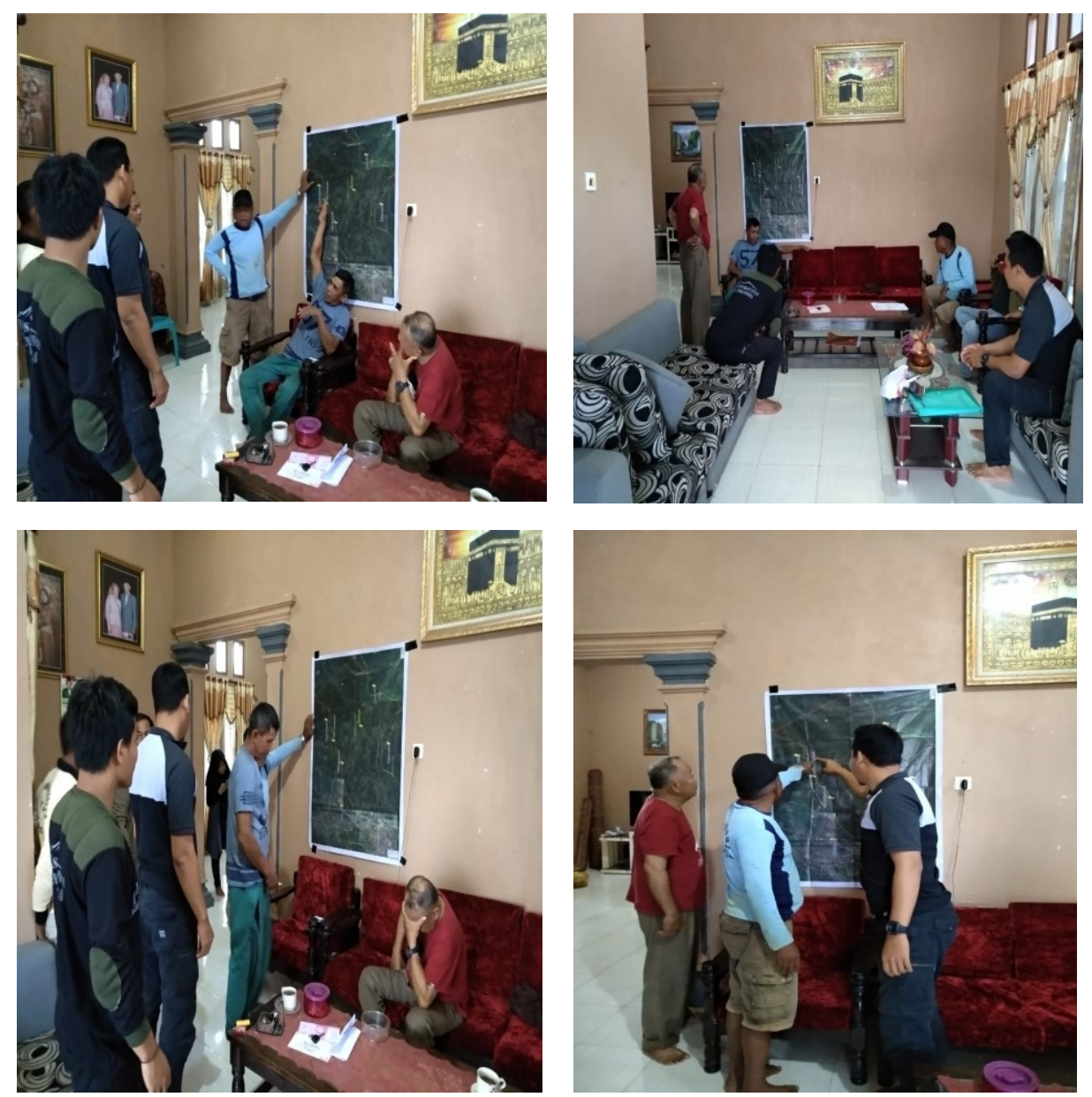

Gambar 1: FGD dengan Kelompok Masyarakat dan BPD Desa Tombang

Adapun teknis pelaksanaan kegitan tanda batas akan diuraikan berikut:

\section{a) Plat Batas}

Pemasangan plat batas dilaksanakan pada areal kelola ijin Perhutanan Sosial. Pemasangan plat batas dipasang pada titik-titik ukur sesuai dengan yang direncanakan pada peta kerja sepanjang trayek batas areal kelola dengan jarak antar pal adalah \pm 100 meter. Plat batas terbuat dari plat seng yang ukurannya $30 \mathrm{~cm}$ x $20 \mathrm{~cm}$ berwarna kuning dengan tulisan berwarna hitam dan dipasang pada patok kayu sebagaimana pada Gambar 2.

\section{b) Penomoran Plat Batas}

Plat seng dipasang menghadap keluar areal kelola Perhutanan Sosial. Plat seng dituliskan huruf singkatan yaitu HD (= Hutan Desa), HKm ( = Hutan Kemasyarakatan), HTR (= Hutan Tanaman Rakyat) + Rimba Lestari (Nama Kelompok). Pemberian nomor secara berurut dari angka 1 sampai seterusnya.

\section{c) Pengukuran Batas}

Kegiatan pengukuran batas dilakukan dengan penggunaan GPS dan didukung dengan kompas sebagai petunjuk arah. Sebelum pengukuran batas dilaksanakan, terlebih dahulu dilakukan kalibrasi GPS. Kemudian, penentuan titik ikat di lapangan sesuai dengan koordinat titik pasti/ titik kontrol/ titik markant peta kerja. 
To Maega | Jurnal Pengabdian Masyarakat

P-ISSN: 2622-6332 \& E-ISSN: 2622-6340

TO MAEGA Volume 2 Nomor 1, Februari 2019, hlm : 30-37
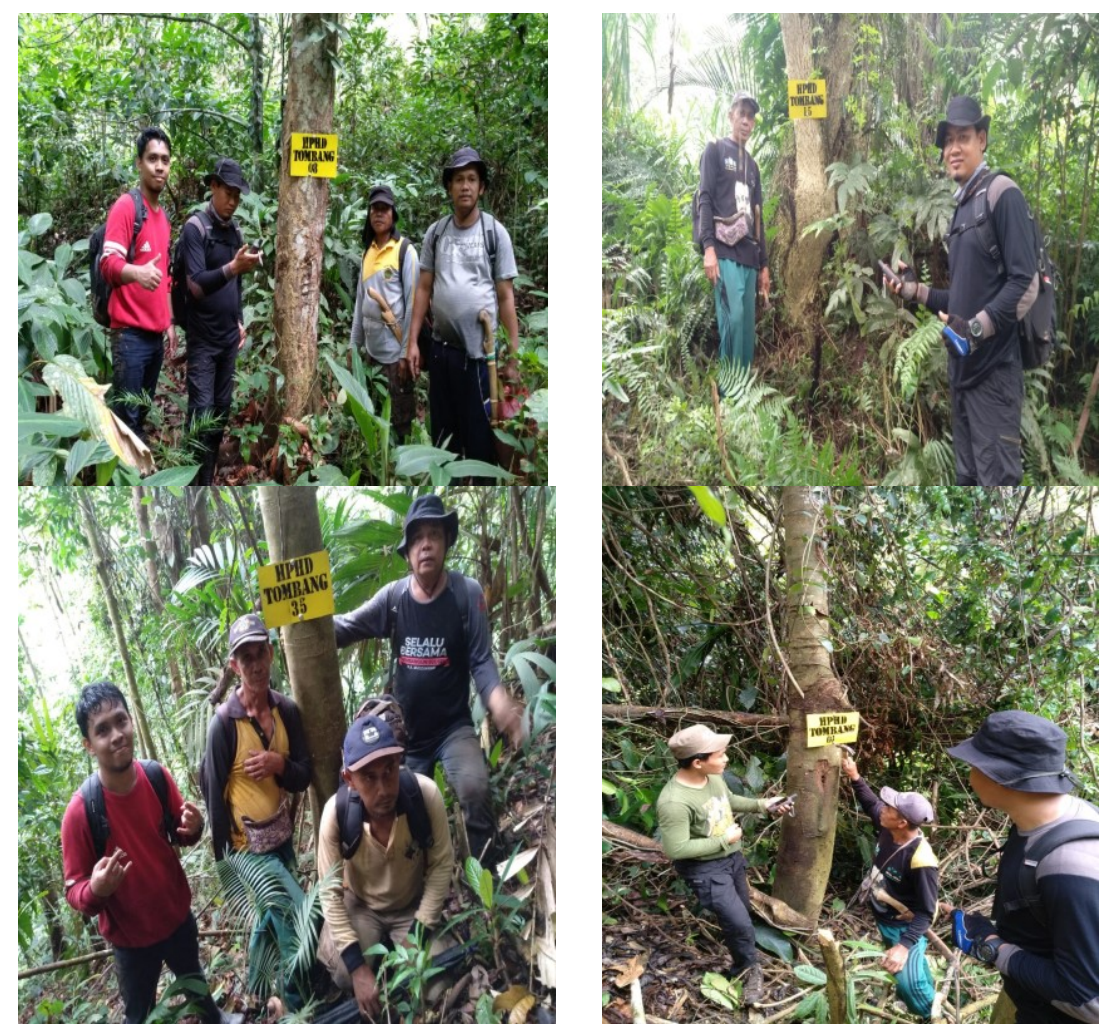

Gambar 2. Pengambilan Titik Koordinat dan Pemasangan Plat HPHD Desa Tombang
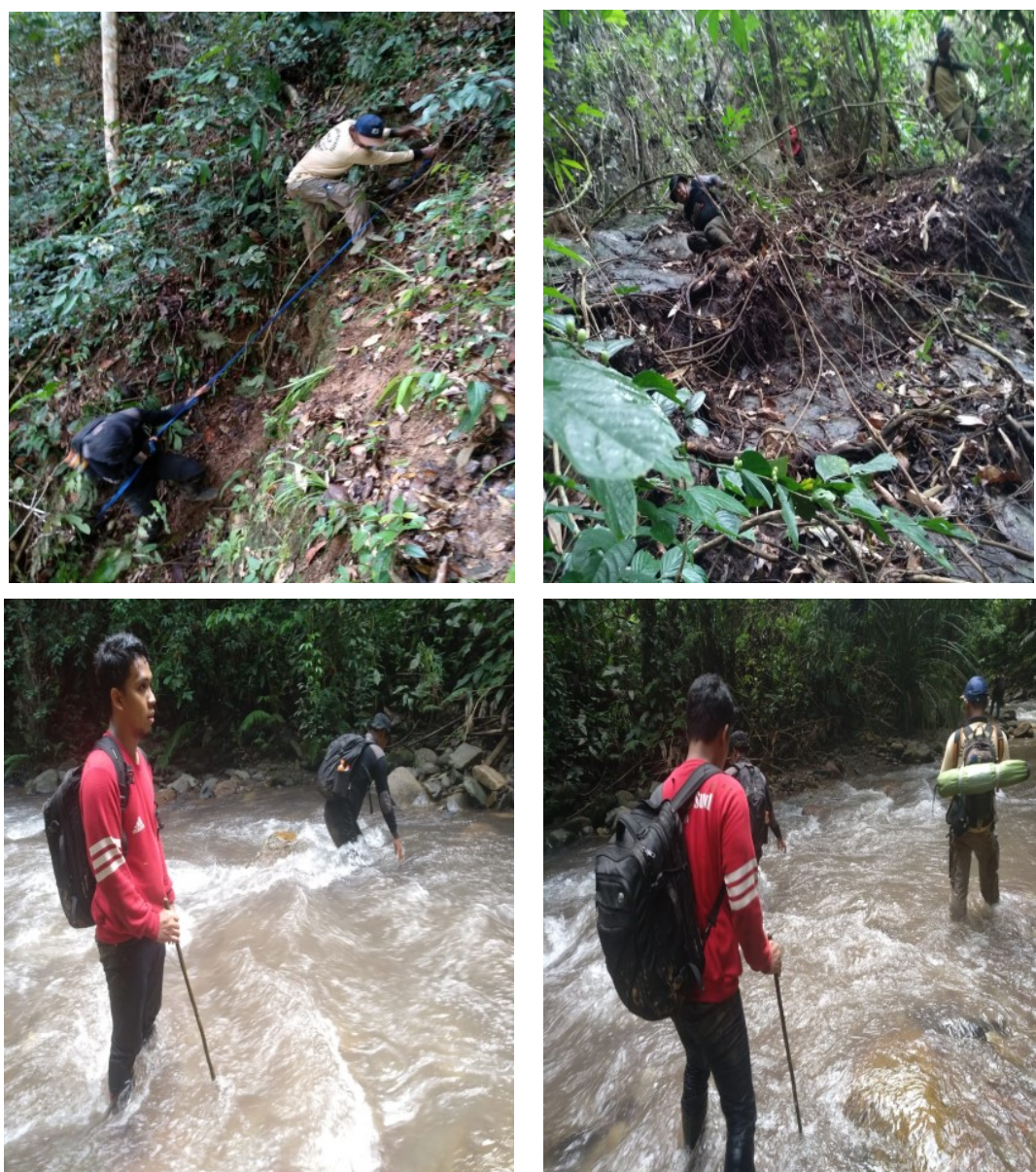

Gambar 3: Jalur Pengambilan Titik Koordinat

To Maega, 2(1), Februari 2019| 33 


\section{Pembuatan Peta}

Pembuatan peta berdasarkan hasil download data GPS yang menggunakan metode differential positioning ke dalam peta hasil tata batas areal kerja sebagaimana pada Tabel 1 . Peta hasil tata batas tersebut dilengkapi dengan layer sungai, jalan setapak, garis kontur dan informasi lainnya yang bersumber dari Peta Rupa Bumi Indonesia dengan skala besar. Pada berita acara tata batas Tabel 1 menjelaskan pengukuran batas areal kerja dengan mencantumkan nomor tanda batas, koordinat, dan jarak.

\section{Hasil Pelaksanaan}

Pelaksanaan kegiatan Penandaan Batas Areal Kerja HPHD Tombang yaitu sebagai berikutt:

a. Penandaan Batas

Kegiatan penandaan batas dilaksanakan pada tanggal 13 s/d 16 Desember tahun 2018, pada wilayah Kawasan Hutan Lindung (HL) yang pelaksananya terdiri dari 3 (tiga) orang Pelaksana, 2 (dua) orang Pendamping serta disaksikan oleh 2 (dua) orang saksi dari Desa Tombang dan Universitas Andi Djemma, serta ada volunteer dari mahasiswa Fakultas Kehutanan Universitas Andi Djemma.

b. Hasil pemasangan tanda batas di lapangan sesuai Peta Kerja.

Dalam menentukan titik batas awal (T0) berada pada koordinat geografis menggunakan reciever GPS, yaitu pada Lintang $2^{\circ} 54^{\prime} 52,179 " S$ dan Bujur Timur 1205'54,582" E, berupa perempatan jalan yang merupakan batas Desa Tombang dan Kelurahan Sumarambu, Kota Palopo. Dari hasil penandaan batas Areal Kerja HPHD Tombang, ada beberapa perubahan titik koordinat yang disepakati oleh tim di lapangan bahwa ada beberapa titik koordinat yang tidak masuk ke dalam batas areal kerja HPHD Tombang dan membuat titik baru serta sebelas titik lainnya tidak memungkinkan dijangkau oleh tim karena faktor medan atau jalur yang sangat terjal dan berbatu dengan kemiringan kurang lebih 90\%.

Titik-titik batas areal kerja setelah dilakukan pemasangan tanda batas adalah sebagaimana tabel 1 berikut :

Tabel 1. Koordinat Hasil Penandaan Plat batas

\begin{tabular}{|c|c|c|c|c|c|c|}
\hline \multirow{2}{*}{$\begin{array}{l}\text { PLAT } \\
\text { BATAS }\end{array}$} & \multirow{2}{*}{ TRAYEK } & \multicolumn{2}{|c|}{ KOORDINAT UTM } & \multicolumn{2}{|c|}{ KOORDINAT GEOGRAFIS } & \multirow{2}{*}{ JARAK (M) } \\
\hline & & $\mathbf{X}$ & $\mathbf{Y}$ & $\mathbf{x}$ & $\mathbf{Y}$ & \\
\hline 1 & Titik 1 -2 & 177411.8353 & 9677442.455 & $120^{\circ} 5^{\prime} 54,582^{\prime \prime} \mathrm{E}$ & $2^{\circ} 54^{\prime} 52,179 " \mathrm{~S}$ & 99.98 \\
\hline 2 & Titik $2-3$ & 177366.8932 & 9677353.143 & $120^{\circ} 5^{\prime} 53,120^{\prime \prime} \mathrm{E}$ & $2^{\circ} 54^{\prime} 55,080^{\prime \prime} \mathrm{S}$ & 99.98 \\
\hline 3 & Titik $3-4$ & 177321.9511 & 9677263.831 & $120^{\circ} 5^{\prime} 51,659^{\prime \prime} \mathrm{E}$ & $2^{\circ} 54^{\prime} 57,982^{\prime \prime} \mathrm{S}$ & 99.17 \\
\hline 4 & Titik 4-5 & 177270.9897 & 9677178.759 & $120^{\circ} 5^{\prime} 50,003^{\prime \prime} \mathrm{E}$ & $2^{\circ} 55^{\prime} 0,745^{\prime \prime} S$ & 99.98 \\
\hline 5 & Titik $5-6$ & 177202.0325 & 9677106.362 & $120^{\circ} 5^{\prime} 47,766^{\prime \prime} \mathrm{E}$ & $2^{\circ} 55^{\prime} 3,094^{\prime \prime} \mathrm{S}$ & 90.02 \\
\hline 6 & Titik $6-7$ & 177116.2829 & 9677078.967 & $120^{\circ} 5^{\prime} 44,990^{\prime \prime} \mathrm{E}$ & $2^{\circ} 55^{\prime} 3,978 " \mathrm{~S}$ & 89.08 \\
\hline 7 & Titik $7-8$ & 177030.1085 & 9677056.385 & $120^{\circ} 5^{\prime} 42,200^{\prime \prime} \mathrm{E}$ & $2^{\circ} 55^{\prime} 4,705^{\prime \prime} \mathrm{S}$ & 91.61 \\
\hline
\end{tabular}


To Maega | Jurnal Pengabdian Masyarakat

P-ISSN: 2622-6332 \& E-ISSN: 2622-6340

TO MAEGA Volume 2 Nomor 1, Februari 2019, hlm : 30-37

\begin{tabular}{|c|c|c|c|c|c|c|}
\hline \multirow{2}{*}{$\begin{array}{l}\text { PLAT } \\
\text { BATAS }\end{array}$} & \multirow{2}{*}{ TRAYEK } & \multicolumn{2}{|c|}{ KOORDINAT UTM } & \multicolumn{2}{|c|}{ KOORDINAT GEOGRAFIS } & \multirow{2}{*}{ JARAK (M) } \\
\hline & & $\mathbf{x}$ & $\mathbf{Y}$ & $\mathbf{X}$ & $\mathbf{Y}$ & \\
\hline 8 & Titik 8 -9 & 176938.9681 & 9677065.64 & $120^{\circ} 5^{\prime} 39,252^{\prime \prime} \mathrm{E}$ & $2^{\circ} 55^{\prime} 4,396 " \mathrm{~S}$ & 94.27 \\
\hline 9 & Titik $9-10$ & 176906.4812 & 9676977.145 & $120^{\circ} 5^{\prime} 38,194^{\prime \prime} \mathrm{E}$ & $2^{\circ} 55^{\prime} 7,272^{\prime \prime} \mathrm{S}$ & 93.01 \\
\hline 10 & Titik $10-11$ & 176827.3548 & 9676928.265 & $120^{\circ} 5^{\prime} 35,630^{\prime \prime} \mathrm{E}$ & $2^{\circ} 55^{\prime} 8,855^{\prime \prime} \mathrm{S}$ & 82.82 \\
\hline 11 & Titik $11-12$ & 176767.6306 & 9676870.895 & $120^{\circ} 5^{\prime} 33,693 " \mathrm{E}$ & $2^{\circ} 55^{\prime} 10,716^{\prime \prime} \mathrm{S}$ & 95.62 \\
\hline 12 & Titik $12-13$ & 176803.6614 & 9676782.328 & $120^{\circ} 5^{\prime} 34,851^{\prime \prime} \mathrm{E}$ & $2^{\circ} 55^{\prime} 13,600 " \mathrm{~S}$ & 99.65 \\
\hline 13 & Titik $13-14$ & 176714.3701 & 9676738.091 & $120^{\circ} 5^{\prime} 31,958^{\prime \prime} \mathrm{E}$ & $2^{\circ} 55^{\prime} 15,032 " \mathrm{~S}$ & 96.60 \\
\hline 14 & Titik $14-15$ & 176637.2625 & 9676679.91 & $120^{\circ} 5^{\prime} 29,459 " \mathrm{E}$ & $2^{\circ} 55^{\prime} 16,918 " \mathrm{~S}$ & 97.34 \\
\hline 15 & Titik $15-16$ & 176582.1829 & 9676599.647 & $120^{\circ} 5^{\prime} 27,670^{\prime \prime} \mathrm{E}$ & $2^{\circ} 55^{\prime} 19,524 " \mathrm{~S}$ & 98.25 \\
\hline 16 & Titik $16-17$ & 176534.89 & 9676513.533 & $120^{\circ} 5^{\prime} 26,133^{\prime \prime} \mathrm{E}$ & $2^{\circ} 55^{\prime} 22,321 " \mathrm{~S}$ & 98.86 \\
\hline 17 & Titik $17-18$ & 176514.9576 & 9676416.708 & $120^{\circ} 5^{\prime} 25,480^{\prime \prime} \mathrm{E}$ & $2^{\circ} 55^{\prime} 25,468^{\prime \prime} \mathrm{S}$ & 96.79 \\
\hline 18 & Titik $18-19$ & 176461.0225 & 9676336.335 & $120^{\circ} 5^{\prime} 23,728^{\prime \prime} \mathrm{E}$ & $2^{\circ} 55^{\prime} 28,078 " \mathrm{~S}$ & 97.02 \\
\hline 19 & Titik $19-20$ & 176407.4238 & 9676255.468 & $120^{\circ} 5^{\prime} 21,988^{\prime \prime} \mathrm{E}$ & $2^{\circ} 55^{\prime} 30,704^{\prime \prime} \mathrm{S}$ & 93.72 \\
\hline 20 & Titik $20-21$ & 176345.1381 & 9676185.438 & $120^{\circ} 5^{\prime} 19,967^{\prime \prime} \mathrm{E}$ & $2^{\circ} 55^{\prime} 32,977 " \mathrm{~S}$ & 98.80 \\
\hline 21 & Titik $21-22$ & 176246.9779 & 9676196.696 & $120^{\circ} 5^{\prime} 16,792^{\prime \prime} \mathrm{E}$ & $2^{\circ} 55^{\prime} 32,602 " \mathrm{~S}$ & 86.67 \\
\hline 22 & Titik $22-23$ & 176163.9598 & 9676221.585 & $120^{\circ} 5^{\prime} 14,108^{\prime \prime} \mathrm{E}$ & $2^{\circ} 55^{\prime} 31,786 " \mathrm{~S}$ & 99.98 \\
\hline 23 & Titik $23-24$ & 176105.6968 & 9676302.839 & $120^{\circ} 5^{\prime} 12,230^{\prime \prime} \mathrm{E}$ & $2^{\circ} 55^{\prime} 29,138^{\prime \prime} \mathrm{S}$ & 99.98 \\
\hline 24 & Titik $24-25$ & 176047.4339 & 9676384.094 & $120^{\circ} 5^{\prime} 10,352^{\prime \prime} \mathrm{E}$ & $2^{\circ} 55^{\prime} 26,490 " \mathrm{~S}$ & 99.98 \\
\hline 25 & Titik $25-26$ & 175989.171 & 9676465.348 & $120^{\circ} 5^{\prime} 8,474^{\prime \prime} \mathrm{E}$ & $2^{\circ} 55^{\prime} 23,842^{\prime \prime} \mathrm{S}$ & 99.98 \\
\hline 26 & Titik $26-27$ & 175930.9082 & 9676546.603 & $120^{\circ} 5^{\prime} 6,596^{\prime \prime} \mathrm{E}$ & $2^{\circ} 55^{\prime} 21,194 " \mathrm{~S}$ & 99.98 \\
\hline 27 & Titik $27-28$ & 175872.6454 & 9676627.857 & $120^{\circ} 5^{\prime} 4,718^{\prime \prime} \mathrm{E}$ & $2^{\circ} 55^{\prime} 18,546 " \mathrm{~S}$ & 99.98 \\
\hline 28 & Titik $28-29$ & 175814.3827 & 9676709.112 & $120^{\circ} 5^{\prime} 2,840^{\prime \prime} \mathrm{E}$ & $2^{\circ} 55^{\prime} 15,898 " \mathrm{~S}$ & 99.98 \\
\hline 29 & Titik $29-30$ & 175756.1201 & 9676790.367 & $120^{\circ} 5^{\prime} 0,961^{\prime \prime} \mathrm{E}$ & $2^{\circ} 55^{\prime} 13,250^{\prime \prime} \mathrm{S}$ & 99.98 \\
\hline 30 & Titik $30-31$ & 175697.8575 & 9676871.622 & $120^{\circ} 4^{\prime} 59,083^{\prime \prime} \mathrm{E}$ & $2^{\circ} 55^{\prime} 10,602 " \mathrm{~S}$ & 99.98 \\
\hline 31 & Titik $31-32$ & 175639.5949 & 9676952.878 & $120^{\circ} 4^{\prime} 57,205^{\prime \prime} \mathrm{E}$ & $2^{\circ} 55^{\prime} 7,955^{\prime \prime} \mathrm{S}$ & 99.98 \\
\hline 32 & Titik $32-33$ & 175581.3324 & 9677034.133 & $120^{\circ} 44^{\prime} 55,327^{\prime \prime} \mathrm{E}$ & $2^{\circ} 55^{\prime} 5,307^{\prime \prime} \mathrm{S}$ & 99.98 \\
\hline 33 & Titik $33-34$ & 175523.07 & 9677115.389 & $120^{\circ} 4^{\prime} 53,449^{\prime \prime} \mathrm{E}$ & $2^{\circ} 55^{\prime} 2,659^{\prime \prime} \mathrm{S}$ & 99.99 \\
\hline 34 & Titik $34-35$ & 175464.8076 & 9677196.645 & $120^{\circ} 4^{\prime} 51,571 " \mathrm{E}$ & $2^{\circ} 55^{\prime} 0,011^{\prime \prime} \mathrm{S}$ & 99.99 \\
\hline 35 & Titik $35-36$ & 175406.5452 & 9677277.901 & $120^{\circ} 4^{\prime} 49,693^{\prime \prime} \mathrm{E}$ & $2^{\circ} 54^{\prime} 57,363^{\prime \prime} \mathrm{S}$ & 99.99 \\
\hline 36 & Titik $36-37$ & 175348.283 & 9677359.157 & $120^{\circ} 4^{\prime} 47,815^{\prime \prime} \mathrm{E}$ & $2^{\circ} 54^{\prime} 54,715^{\prime \prime} \mathrm{S}$ & 99.99 \\
\hline 37 & Titik $37-38$ & 175290.0207 & 9677440.413 & $120^{\circ} 4^{\prime} 45,937 " \mathrm{E}$ & $2^{\circ} 54^{\prime} 52,067 " \mathrm{~S}$ & 99.99 \\
\hline 38 & Titik $38-39$ & 175231.7586 & 9677521.67 & $120^{\circ} 4^{\prime} 44,059 " \mathrm{E}$ & $2^{\circ} 54^{\prime} 49,419 " \mathrm{~S}$ & 99.99 \\
\hline 39 & Titik $39-40$ & 175173.4964 & 9677602.926 & $120^{\circ} 4^{\prime} 42,181^{\prime \prime} \mathrm{E}$ & $2^{\circ} 54^{\prime} 46,771 " \mathrm{~S}$ & 99.99 \\
\hline 40 & Titik $40-41$ & 175115.2344 & 9677684.183 & $120^{\circ} 4^{\prime} 40,303^{\prime \prime} \mathrm{E}$ & $2^{\circ} 54^{\prime} 44,123 " \mathrm{~S}$ & 99.99 \\
\hline
\end{tabular}


To Maega | Jurnal Pengabdian Masyarakat

P-ISSN: 2622-6332 \& E-ISSN: 2622-6340

TO MAEGA Volume 2 Nomor 1, Februari 2019, hlm : 30-37

\begin{tabular}{|c|c|c|c|c|c|c|}
\hline \multirow{2}{*}{$\begin{array}{l}\text { PLAT } \\
\text { BATAS }\end{array}$} & \multirow{2}{*}{ TRAYEK } & \multicolumn{2}{|c|}{ KOORDINAT UTM } & \multicolumn{2}{|c|}{ KOORDINAT GEOGRAFIS } & \multirow{2}{*}{ JARAK (M) } \\
\hline & & $\mathbf{x}$ & $\mathbf{Y}$ & $\mathbf{X}$ & $\mathbf{Y}$ & \\
\hline 41 & Titik $41-42$ & 175056.9723 & 9677765.44 & $120^{\circ} 4^{\prime} 38,425^{\prime \prime} \mathrm{E}$ & $2^{\circ} 54^{\prime} 41,475^{\prime \prime} \mathrm{S}$ & 99.99 \\
\hline 42 & Titik $42-43$ & 174998.7104 & 9677846.697 & $120^{\circ} 4^{\prime} 36,547^{\prime \prime} \mathrm{E}$ & $2^{\circ} 54^{\prime} 38,827^{\prime \prime} \mathrm{S}$ & 99.99 \\
\hline 43 & Titik $43-44$ & 174940.4485 & 9677927.954 & $120^{\circ} 4^{\prime} 34,669^{\prime \prime} \mathrm{E}$ & $2^{\circ} 54^{\prime} 36,179 " \mathrm{~S}$ & 99.99 \\
\hline 44 & Titik $44-45$ & 174882.1866 & 9678009.212 & $120^{\circ} 4^{\prime} 32,791^{\prime \prime} \mathrm{E}$ & $2^{\circ} 54^{\prime} 33,531 " \mathrm{~S}$ & 99.99 \\
\hline 45 & Titik $45-46$ & 174823.9248 & 9678090.469 & $120^{\circ} 4^{\prime} 30,913^{\prime \prime} \mathrm{E}$ & $2^{\circ} 54^{\prime} 30,883^{\prime \prime} \mathrm{S}$ & 99.99 \\
\hline 46 & Titik $46-47$ & 174765.6631 & 9678171.727 & $120^{\circ} 4^{\prime} 29,035^{\prime \prime} \mathrm{E}$ & $2^{\circ} 54^{\prime} 28,235^{\prime \prime} \mathrm{S}$ & 99.99 \\
\hline 47 & Titik $47-48$ & 174707.4014 & 9678252.985 & $120^{\circ} 4^{\prime} 27,157^{\prime \prime} \mathrm{E}$ & $2^{\circ} 54^{\prime} 25,588^{\prime \prime} \mathrm{S}$ & 83.77 \\
\hline 48 & Titik $48-49$ & 174745.3986 & 9678327.644 & $120^{\circ} 4^{\prime} 28,392^{\prime \prime} \mathrm{E}$ & $2^{\circ} 54^{\prime} 23,162^{\prime \prime} \mathrm{S}$ & 99.99 \\
\hline 49 & Titik $49-50$ & 174814.2034 & 9678400.192 & $120^{\circ} 4^{\prime} 30,624^{\prime \prime} \mathrm{E}$ & $2^{\circ} 54^{\prime} 20,808^{\prime \prime} \mathrm{S}$ & 99.99 \\
\hline 50 & Titik $50-51$ & 174883.0083 & 9678472.739 & $120^{\circ} 4^{\prime} 32,856^{\prime \prime} \mathrm{E}$ & $2^{\circ} 54^{\prime} 18,454^{\prime \prime} \mathrm{S}$ & 99.99 \\
\hline 51 & Titik $51-52$ & 174951.8131 & 9678545.286 & $120^{\circ} 4^{\prime} 35,088^{\prime \prime} \mathrm{E}$ & $2^{\circ} 54^{\prime} 16,100 " \mathrm{~S}$ & 99.99 \\
\hline 52 & Titik $52-53$ & 175020.618 & 9678617.833 & $120^{\circ} 4^{\prime} 37,320^{\prime \prime} \mathrm{E}$ & $2^{\circ} 54^{\prime} 13,747^{\prime \prime} \mathrm{S}$ & 99.99 \\
\hline 53 & Titik $53-54$ & 175089.4229 & 9678690.38 & $120^{\circ} 4^{\prime} 39,552 " \mathrm{E}$ & $2^{\circ} 54^{\prime} 11,393^{\prime \prime} \mathrm{S}$ & 99.99 \\
\hline 54 & Titik $54-55$ & 175158.2278 & 9678762.927 & $120^{\circ} 4^{\prime} 41,784^{\prime \prime} \mathrm{E}$ & $2^{\circ} 54^{\prime} 9,039 " \mathrm{~S}$ & 99.99 \\
\hline 55 & Titik $55-56$ & 175227.0327 & 9678835.473 & $120^{\circ} 4^{\prime} 44,016^{\prime \prime} \mathrm{E}$ & $2^{\circ} 54^{\prime} 6,685^{\prime \prime} \mathrm{S}$ & 99.99 \\
\hline 56 & Titik $56-57$ & 175295.8376 & 9678908.02 & $120^{\circ} 4^{\prime} 46,248^{\prime \prime} \mathrm{E}$ & $2^{\circ} 54^{\prime} 4,331^{\prime \prime} \mathrm{S}$ & 99.99 \\
\hline 57 & Titik $57-58$ & 175364.6425 & 9678980.566 & $120^{\circ} 4^{\prime} 48,480^{\prime \prime} \mathrm{E}$ & $2^{\circ} 54^{\prime} 1,977^{\prime \prime} \mathrm{S}$ & 99.99 \\
\hline 58 & Titik 58 -59 & 175433.4474 & 9679053.112 & $120^{\circ} 4^{\prime} 50,712^{\prime \prime} \mathrm{E}$ & $2^{\circ} 53^{\prime} 59,623^{\prime \prime} \mathrm{S}$ & 99.99 \\
\hline 59 & Titik $59-60$ & 175502.2523 & 9679125.658 & $120^{\circ} 4^{\prime} 52,944^{\prime \prime} \mathrm{E}$ & $2^{\circ} 53^{\prime} 57,269^{\prime \prime} \mathrm{S}$ & 99.98 \\
\hline 60 & Titik $60-61$ & 175571.0573 & 9679198.204 & $120^{\circ} 4^{\prime} 55,176 " \mathrm{E}$ & $2^{\circ} 53^{\prime} 54,915^{\prime \prime} \mathrm{S}$ & 99.98 \\
\hline 61 & Titik $61-62$ & 175639.8622 & 9679270.749 & $120^{\circ} 4^{\prime} 57,408^{\prime \prime} \mathrm{E}$ & $2^{\circ} 53^{\prime} 52,561 " \mathrm{~S}$ & 99.98 \\
\hline 62 & Titik 62 & 175708.6671 & 9679343.295 & $120^{\circ} 4^{\prime} 59,640 " \mathrm{E}$ & $2^{\circ} 53^{\prime} 50,207 " \mathrm{~S}$ & 5982 \\
\hline
\end{tabular}

Tabel 2. Perubahan/Pergeseran Titik Koordinat

\begin{tabular}{|c|c|c|c|c|}
\hline \multirow{2}{*}{$\begin{array}{c}\text { Plat } \\
\text { Batas }\end{array}$} & \multirow{2}{*}{ Trayek } & \multicolumn{2}{|c|}{ Kordinat Geografis } & \multirow{2}{*}{ Jarak(M) } \\
\cline { 2 - 4 } & & $\mathrm{X}$ & $\mathrm{Y}$ & \multirow{2}{*}{94.27} \\
\hline 8 & Titik $8-9$ & $120^{\circ} 5^{\prime} 39.3^{\prime \prime} \mathrm{E}$ & $2^{\circ} 55^{\prime} 4,4^{\prime \prime} \mathrm{S}$ & 95.62 \\
\hline 11 & Titik $11-12$ & $120^{\circ} 5^{\prime} 33,9^{\prime \prime} \mathrm{E}$ & $2^{\circ} 55^{\prime} 12,5^{\prime \prime} \mathrm{S}$ & 96.6 \\
\hline 13 & Titik $13-14$ & $120^{\circ} 5^{\prime} 31,17^{\prime \prime} \mathrm{E}$ & $2^{\circ} 55^{\prime} 14,1^{\prime \prime} \mathrm{S}$ & 97.34 \\
\hline 14 & Titik $14-15$ & $120^{\circ} 5^{\prime} 28,8^{\prime \prime} \mathrm{E}$ & $2^{\circ} 55^{\prime} 16,5^{\prime \prime} \mathrm{S}$ & 98.25 \\
\hline 15 & Titik $15-16$ & $120^{\circ} 5^{\prime} 27,3^{\prime \prime} \mathrm{E}$ & $2^{\circ} 55^{\prime} 19,9^{\prime \prime} \mathrm{S}$ & 98.86 \\
\hline 16 & Titik $16-17$ & $120^{\circ} 5^{\prime} 26,0^{\prime \prime} \mathrm{E}$ & $2^{\circ} 55^{\prime} 22,0^{\prime \prime} \mathrm{S}$ & 96.79 \\
\hline 17 & Titik $17-18$ & $120^{\circ} 5^{\prime} 24,8^{\prime \prime} \mathrm{E}$ & $2^{\circ} 55^{\prime} 25,2^{\prime \prime} \mathrm{S}$ & 97.02 \\
\hline 18 & Titik $18-19$ & $120^{\circ} 5^{\prime} 22,1^{\prime \prime} \mathrm{E}$ & $2^{\circ} 55^{\prime} 28,6^{\prime \prime} \mathrm{S}$ & 93.72 \\
\hline 20 & Titik $19-20$ & $120^{\circ} 5^{\prime} 20,5^{\prime \prime} \mathrm{E}$ & $2^{\circ} 55^{\prime} 30,2^{\prime \prime} \mathrm{S}$ & 98.8 \\
\hline
\end{tabular}


TO MAEGA Volume 2 Nomor 1, Februari 2019, hlm : 30-37

\begin{tabular}{|l|l|l|l|l|}
\hline 21 & Titik 21-22 & $120^{\circ} 5^{\prime} 16,8^{\prime \prime} \mathrm{E}$ & $2^{\circ} 55^{\prime} 32,0^{\prime \prime} \mathrm{S}$ & 86.67 \\
\hline 22 & Titik 22 -23 & $120^{\circ} 5^{\prime} 15,3^{\prime \prime} \mathrm{E}$ & $2^{\circ} 55^{\prime} 28,8^{\prime \prime} \mathrm{S}$ & 99.98 \\
\hline 23 & Titik 23-24 & $120^{\circ} 5^{\prime} 12,3^{\prime \prime} \mathrm{E}$ & $2^{\circ} 55^{\prime} 26,4^{\prime \prime} \mathrm{S}$ & 99.98 \\
\hline 24 & Titik 24 -25 & $120^{\circ} 5^{\prime} 11,8^{\prime \prime} \mathrm{E}$ & $2^{\circ} 55^{\prime} 25,6^{\prime \prime} \mathrm{S}$ & 99.98 \\
\hline
\end{tabular}

Rintis batas dibuat selebar \pm 1 meter yang menghubungkan satu titik dengan titik berikutnya dengan keseluruhan panjang batas \pm 5.982 meter. Titik-titik batas berupa plat seng dengan memberikan kode inisial HPHD Tombang 1, HPHD Tombang 2, ..., dst sebanyak 62 (enam puluh dua) buah plat. Adapun Batas Areal Kerja HPHD Tombang meliputi:

1) Sebelah Utara berbatasan dengan Desa Ilan Batu.

2) Sebelah Timur berbatasan dengan Kawasan Hutan Rakyat (HTR) Dusun Batu Buaya Desa Tombang.

3) Sebelah Selatan berbatasan dengan Kawasan Hutan Lindung (HL) Kelurahan Padang Lambe.

4) Sebelah Barat berbatasan dengan Hutan Konservasi TWA Nanggala 3 Kelurahan Battang Barat Kota Palopo.

\section{SIMPULAN}

Dari hasil kegiatan penandaan tata batas sederhana HPHD Tombang yang dilakukan pada tanggal 14 sampai dengan 16 desember 2018, oleh tim pengelola, pendamping, saksi dan volunteer. Dari 62 titik, ada beberapa yg dilakukan pergeseran titik karena koordinat tidak masuk ke dalam areal kerja HPHD Tombang serta ada beberapa titik yang tidak dapat dijangkau dikarenakan medan yang berat seperti tebing berbatu dengan kemiringan diperkirakan $90 \%$.

\section{DAFTAR PUSTAKA}

Asnuddin, A. (2010). Pendekatan partisipatif dalam pembangunan proyek infrastruktur Perdesaan di Indonesia. SMARTek, 8(3).

Fisu, A. A., \& Marzaman, L. U. (2018). Pemetaan Partisipatif Kampung Pesisir Kelurahan Tallo Kota Makassar. To Maega| Jurnal Pengabdian Masyarakat, 1(1).

Peraturan Menteri Lingkungan Hidup dan Kehutanan No: P.14/Menlhk/Setjen/OTL.O/I/2016 Peraturan Menteri Lingkungan Hidup dan Kehutanan No: P.83/MENLHK/SETJEN/KUM.1/10/2016 tentang Perhutanan Sosial

Peraturan Menteri Kehutanan No: P. 44/Menhut-II/2012 tentang Pengukuhan Kawasan Hutan

Peraturan Dirjen Planologi Kehutanan dan Tata Lingkungan No: P.3/PKTL/SEKDIT/PLA.2/9/2016 tentang Petunjuk Teknis Pengukuhan Kawasan Hutan

Peraruran Ditjen PSKL No: P. 16/PSKL/SET/PSL.0/11/2016 tentang Pedoman Penyusunan RPHD, RKU-IUPHKm dan RKU-IUPHHKHTR.

Sumanto, S. E. (2009). Kebijakan pengembangan perhutanan sosial dalam perspektif resolusi konflik. Jurnal Analisis Kebijakan Kehutanan, 6(1). 